\title{
EDUKASI MENJALANI HIDUP SEHAT PADA ERA "NEW NORMAL" DI RT 02 RW 03 KELURAHAN SINGOSARI KECAMATAN KEBOMAS KABUPATEN GRESIK
}

\author{
Diah Ratnasari , Riskha Aulia, Noorainny Yunitasari \\ Diploma 3 Farmasi, Fakultas Kesehatan, Universitas Muhammadiyah Gresik \\ Jl. Proklamasi No.54, Gresik 61111 \\ Email: diahratnasari@umg.ac.id
}

\begin{abstract}
Abstrak
Sejak akhir Desember 2019, di Indonesia, jumlah pasien positif COVID-19 terus meningkat bahkan virus ini sudah menyebar melalui transmisi lokal di beberapa provinsi di Indonesia. Per 26 Juni 2020, Jawa Timur memiliki kasus Covid-19 tertinggi di Indonesia. Kabupaten Gresik merupakan salah satu daerah yang termasuk zona merah. Hal ini harus dijadikan perhatian serius oleh masyarakat terutama pada era "New Normal. Sampai saat ini masih belum ditemukan obat yang terbukti secara klinis dapat mengobati COVID-19 ini. Tujuan pengabdian masyarakat ini untuk meningkatkan pemahaman tentang Covid-19 terutama pencegahannya pada masyarakat di zona merah yaitu salah satunya ibu-ibu PKK PKK di RT 02 RW 03 Kelurahan Singosari Kecamatan Kebomas Kabupaten Gresik. Metode yang digunakan yaitu dengan menyampaikan materi dalam bentuk rekaman video yang dibagikan melalui WA Group. Pemahaman materi dilakukan dengan cara masyarakat mengisi kuesioner pretest dan posttest dalam bentuk Google Form. Hasil kegiatan menunjukkan bahwa masyarakat antusias dengan kegiatan ini. Selain itu terjadi peningkatan pemahaman tentang Covid-19.
\end{abstract}

Kata kunci: Covid-19, Jawa Timur, New Normal, Pencegahan

\section{PENDAHULUAN}

Virus Sar-Cov2 merupakan virus yang menyebabkan penyakit Covid-19 yang berasal dari famili Coronavirus dan menimbulkan gejala mulai dari ringan sampai berat. Ada setidaknya dua jenis virus dari famili coronavirus yang diketahui menyebabkan penyakit yang dapat menimbulkan gejala berat seperti Middle East Respiratory Syndrome (MERS) dan Severe Acute Respiratory Syndrome (SARS) (Dirjen Pencegahan Dan Pengendalian Penyakit, 2020).

Coronavirus Disease 2019 (COVID-19) adalah penyakit jenis baru yang belum pernah diidentifikasi sebelumnya pada manusia. Virus penyebab COVID-19 ini dinamakan Sars-CoV-2. Virus corona adalah zoonosis (ditularkan antara hewan dan manusia). Penelitian menyebutkan bahwa SARS ditransmisikan dari kucing luwak ke manusia dan MERS dari unta ke manusia. Adapun, hewan yang menjadi sumber penularan COVID-19 ini masih belum diketahui. COVID19 adalah penyakit menular yang disebabkan oleh jenis coronavirus yang baru ditemukan. Virus baru dan penyakit yang disebabkannya ini tidak dikenal sebelum mulainya wabah di Wuhan, Tiongkok, bulan Desember 2019. COVID-19 ini sekarang menjadi sebuah pandemi yang terjadi di banyak negara di seluruh dunia ( Pencegahan Dan Pengendalian Penyakit, 2020).

Tanda dan gejala umum infeksi COVID-19 antara lain gejala gangguan pernapasan akut seperti demam, batuk dan sesak napas. Masa inkubasi rata-rata 5-6 hari dengan masa inkubasi terpanjang 14 hari. Pada kasus COVID-19 yang berat dapat menyebabkan pneumonia, sindrom pernapasan akut, gagal ginjal, dan bahkan kematian. Tanda-tanda dan gejala klinis yang dilaporkan pada sebagian besar kasus adalah demam, dengan beberapa kasus mengalami kesulitan bernapas, dan hasil rontgen menunjukkan infiltrat pneumonia luas di kedua paru (Dirjen Pencegahan Dan Pengendalian Penyakit, 2020).

Pada 31 Desember 2019, WHO China Country Office melaporkan kasus pneumonia yang tidak diketahui etiologinya di Kota Wuhan, Provinsi Hubei, Cina. Pada tanggal 7 Januari 2020, Cina mengidentifikasi pneumonia yang tidak diketahui etiologinya tersebut sebagai jenis baru coronavirus (coronavirus disease, COVID-19). Pada tanggal 30 Januari 2020 WHO telah menetapkan sebagai Kedaruratan Kesehatan Masyarakat Yang Meresahkan Dunia/ Public Health Emergency of International Concern (KKMMD/PHEIC). Penambahan jumlah kasus 
COVID-19 berlangsung cukup cepat dan sudah terjadi penyebaran antar Negara (Dirjen Pencegahan Dan Pengendalian Penyakit, 2020).

Per 26 Juni 2020, Jawa Timur memiliki kasus Covid-19 tertinggi di Indonesia. Ada 10886

kasus terkonfirmasi, 10137 pasien dalam pengawasan, dan 29166 orang dalam pengawasan. Diantara kasus tersebut, sudah ada beberapa petugas kesehatan yang dilaporkan terinfeksi. Kabupaten Gresik merupakan salah satu daerah yang termasuk zona merah. Zona merah merupakan daerah dengan kasus Covid-19 dengan resiko tinggi yang penyebaran virus tidak terkendali (Gugus Tugas Percepatan Penanganan Covid-19, 2020).

Berdasarkan bukti ilmiah, COVID-19 dapat menular dari manusia ke manusia melalui percikan batuk/bersin (droplet), tidak melalui udara. Orang yang paling berisiko tertular penyakit ini adalah orang yang kontak erat dengan pasien COVID-19 termasuk yang merawat pasien COVID-19. Rekomendasi standar untuk mencegah penyebaran infeksi adalah melalui cuci tangan secara teratur menggunakan sabun dan air bersih, menerapkan etika batuk dan bersin, menghindari kontak secara langsung dengan ternak dan hewan liar serta menghindari kontak dekat dengan siapapun yang menunjukkan gejala penyakit pernapasan seperti batuk dan bersin (Dirjen Pencegahan Dan Pengendalian Penyakit, 2020).

\section{METODE}

Khalayak sasaran pengabdian masyarakat ini yaitu ibu-ibu PKK di RT 02 RW 03 Kelurahan Singosari Kecamatan Kebomas Kabupaten Gresik. Alasan pemilihan khalayak sasaran ini dikarenakan Gresik merupakan salah satu daerah di Jawa Timur yang termasuk kategori zona merah. Di zona merah pada masa pandemic Covid-19 ini tidak diperbolehkan ada kerumunan dan harus adanya social distancing. Kegiatan pengabdian kepada masyarakat ini dilaksanakan pada tanggal 28 Juni 2020 ini berupa edukasi dengan media daring kepada masyarakat dengan tema "Hidup Sehat pada Masa New Normal".

Kegiatan ini mengacu pada Pedoman Pencegahan dan Pengendalian Covid-19 oleh Kementerian Kesehatan RI. Materi yang disampaikan meliputi definisi, penyebab, gejala, target, dampak dan pengobatan Covid-19, serta pencegahan Covid-19 di Era New Normal yang dikemas dalam rekaman video. Rekaman video ini kemudian dibagikan melalui Whatsapp Group. Media ini dipilih dengan pertimbangan Whatsapp pasti sudah dimiliki oleh setiap warga dan sudah biasa dalam pengoperasiannya. Aplikasi ini mudah digunakan dibandingkan lewat media sosial lainnya. Selain itu, materi yang disampaikan dapat disimpan oleh masyarakat dan sewaktu-waktu dapat dipelajari kembali. Adapun tahapan pelaksanaan pengabdian masyarakat ini yaitu:

1. Tim diizinkan masuk WA Group

2. Tim memperkenalkan diri

3. Tim menjelaskan jadwalkegiatan yang akan dilaksanakan di WA GRUP

4. Pretest, ibu-ibu mengisi kuesioner pada link yang dibagikan di WA Group

5. Edukasi tim membagikan video pada WA Group

6. Diskusi interaktif, tim dan ibu-ibu PKK berdiskusi melalui WA Group

7. Postest, ibu-ibu mengisi kuesioner pada link yang dibagikan di WA Group

8. Pembagian souvenir

9. Hasil pretest dan posttest dianalisis dengan cara tabulasi untuk mendapatkan nilai persentase tingkat pengetahuan ibu-ibu tentang Covid-19 baik sebelum maupun sesudah penyuluhan

Instrumen yang digunakan dalam kegiatan ini adalah berupa pemberian soal pretest dan soal posttest. Kedua soal dibuat dalam bentuk google form,sehingga untuk pengerjaan, warga diberikan link google form. Bentuk soal pretest dan posttest yang disediakan adalah berupa pertanyaan tertutup, yaitu responden memilih benar atau salah. Soal pretest dan soal posttest dibuat sama dengan tujuan agar dapat mengetahui ada peningkatan atau tidak pemahaman ibu-ibu tentang Covid-19. Sebelum melakukan pengisian soal pretest dan posttest, responden diminta untuk mengisi identitas diri, yang meliputi nama, umur, pendidikan terakhir, dan pekerjaan. Hal ini dikarenakan perbedaan pendidikan, pekerjaan, dan umur mempengaruhi kemampuan responden dalam menjawab pertanyaan yang diberikan. Dari hasil pengisian pretest dan posttest akan dibandingkan jumlah jawaban benar dari setiap responden. Dari kegiatan ini diharapkan ada perbedaan yang signifikan terkait tingkat pemahaman tentang Covid-19 kepada ibu-ibu PKK RT 02 RW 03 Kelurahan Singosari Kecamatan Kebomas Kabupaten Gresik. 

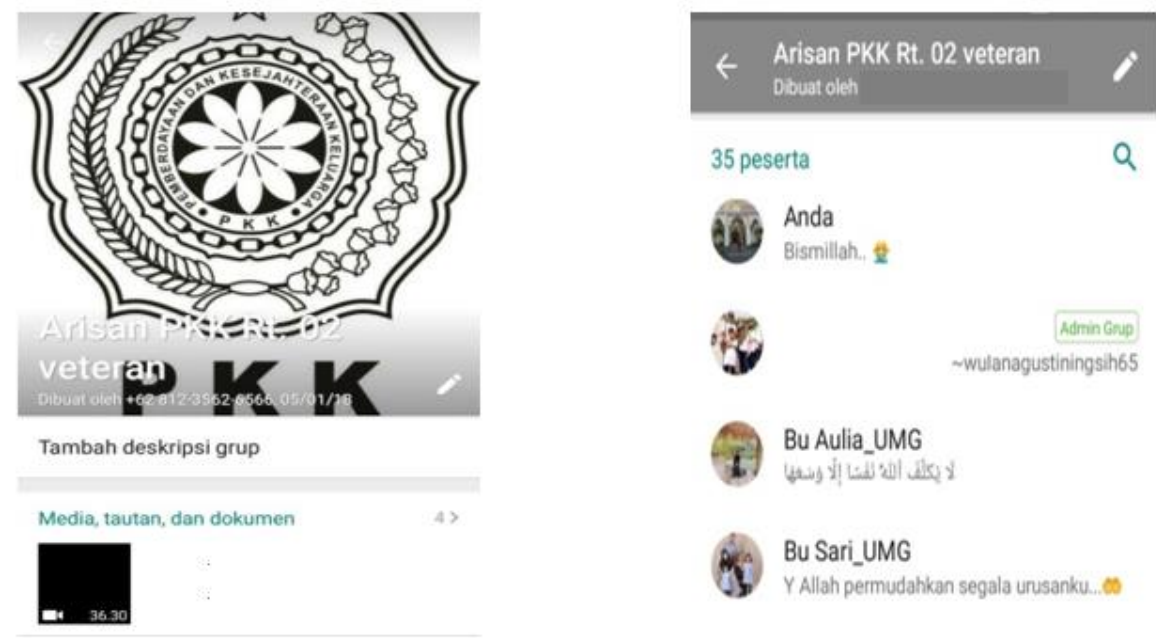

Gambar 1. WA Group
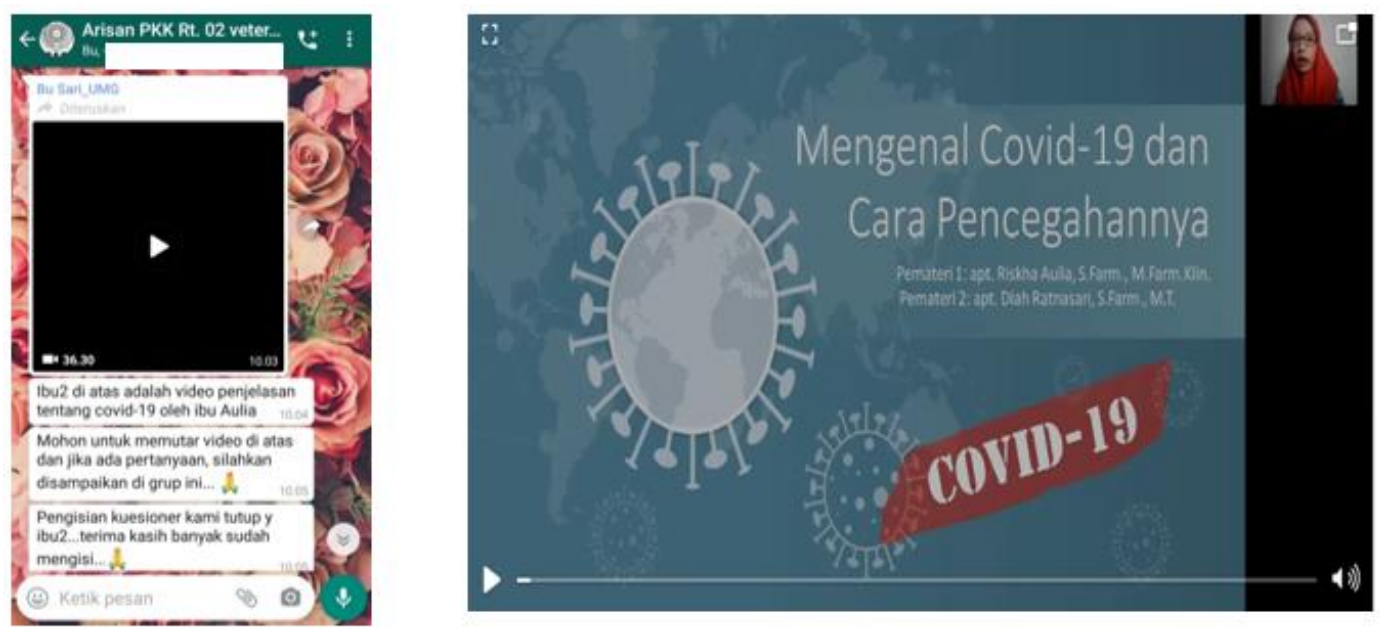

Gambar 2. Screenshot Video yang Dibagikan di WA Group

\section{HASIL DAN PEMBAHASAN}

Dari pelaksanaan kegiatan pengabdian kepada masyarakat yang dilaksanakan dengan ibu-ibu PKK RT 02 RW 03 Kelurahan Singosari Kecamatan Kebomas Kabupaten Gresik dapat disimpulkan bahwa banyak ibu-ibu yang antusias dalam kegiatan ini. Banyak pertanyaan yang disampaikan oleh ibu-ibu PKK RT 02 RW 03 Kelurahan Singosari Kecamatan Kebomas Kabupaten Gresik kepada tim. Cuplikan diskusi interaktif ditampilkan pada Gambar 3.
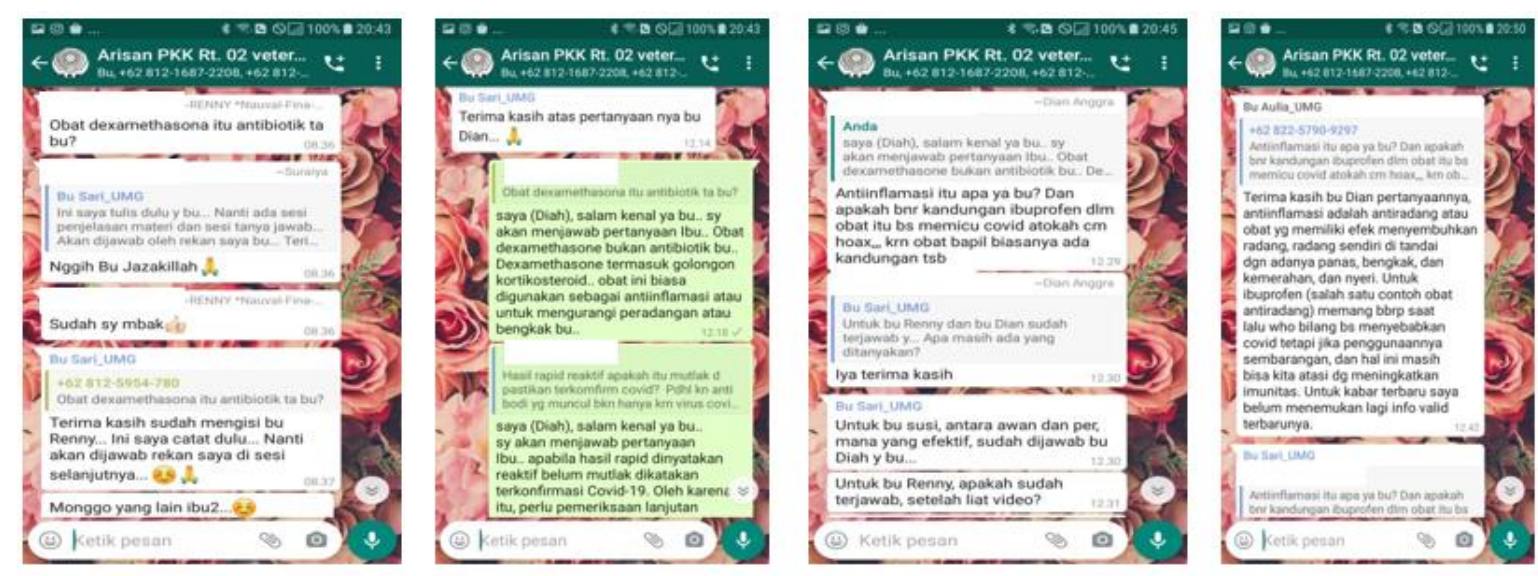

Gambar 3. Screenshoot WA Group 
Selain itu, setelah mengerjakan soal pretest, ada beberapa warga yang merasa kesulitan menjawab dan akhirnya menyampaikan pertanyaan. Selanjutnya setelah dibagikan video edukasi ke WA GRUP, warga yang semula tanya tersebut menyampaikan bahwa pertanyaannya sudah terjawab. Hasil dari kuesioner pre-test di dapatkan bahwa ibu - ibu PKK di lingkungan RT 02 RW 03 Kelurahan Singosari Kecamatan Kebomas Kabupaten Gresik masih kurang paham pada beberapa pertanyaan. Hasil dari pre-test dan post-test disajikan di Tabel 1.

Tabel 1. Hasil Jawaban Benar Pretest dan Post Test

\begin{tabular}{ccc}
\hline Pertanyaan ke- & Pre-test & Post-Test \\
\hline $\mathbf{1}$ & $100 \%$ & $100 \%$ \\
$\mathbf{2}$ & $17 \%$ & $40 \%$ \\
$\mathbf{3}$ & $27 \%$ & $60 \%$ \\
$\mathbf{4}$ & $94 \%$ & $100 \%$ \\
$\mathbf{5}$ & $94 \%$ & $90 \%$ \\
$\mathbf{6}$ & $100 \%$ & $100 \%$ \\
$\mathbf{7}$ & $94 \%$ & $100 \%$ \\
$\mathbf{8}$ & $76 \%$ & $100 \%$ \\
$\mathbf{9}$ & $65 \%$ & $90 \%$ \\
$\mathbf{1 0}$ & $100 \%$ & $100 \%$ \\
$\mathbf{1 1}$ & $100 \%$ & $100 \%$ \\
$\mathbf{1 2}$ & $94 \%$ & $100 \%$ \\
$\mathbf{1 3}$ & $94 \%$ & $100 \%$ \\
$\mathbf{1 4}$ & $53 \%$ & $60 \%$ \\
\hline
\end{tabular}

Dari hasil tersebut sebenarnya dapat diketahui bahwa masyarakat sudah paham dengan Covid-19 dan pencegahannya, namun pada kenyataannya masih ada masyarakat yang tidak menerapkan dengan baik. Berdasarkan Tabel 1 juga dapat disimpulkan bahwa adanya pemutaran video dari pemateri, memberikan penambahan wawasan warga terkait Covid-19. Hal ini dibuktikan dengan adanya peningkatan jawaban benar dari semua pertanyaan, meskipun ada beberapa pertanyaan yang masih belum terjawab benar $100 \%$. Beberapa pertanyaan yang mengalami jumlah peningkatan yang menjawab benar adalah pertanyaan ke-2, 3, 4, 7, 8, 9, 12, 13, dan 14.

Selain itu, pada pertanyaan yang ke-5 mengalami penurunan jumlah warga yang dapat menjawab benar. Dari kondisi ini menyebabkan timbulnya dugaan ada sebagian dari warga yang menjawabnya hanya sekedarnya. Sebenarnya jika semua warga yang awalnya (saat menjawab soal pretest) itu benar-benar paham dengan apa yang dipilih, maka seharusnya tidak mengalami penurunan jumlah warga yang menjawab benar. Seperti inilah resiko dari pemilihan soal pilihan ganda dengan kemungkinan jawaban dua yaitu benar dan salah. Namun, kita harapkan dengan adanya beberapa penambahan jawaban benar di beberapa pertanyaan dapat menunjukkan kalau warga mengalami penambahan wawasan terkait Covid-19. Jadi dengan adanya penambahan wawasan ini, masyarakat lebih waspada menangani Covid-19 sehingga terhindar dari penyakit ini.

\section{DAFTAR PUSTAKA}

Dirjen Pencegahan Dan Pengendalian Penyakit. 2020. Pedoman Pencegahan Dan Pengendalian Coronavirus Disease (COVID-19). Jakarta

Gugus Tugas Percepatan Penanganan Covid-19. 2020. Kasus Provinsi Jawa Timur. Dalam https://covid19.go.id/peta-sebaran diakses pada 26 Juni 2020.

WHO. 2020. Pertanyaan dan Jawabanterkait Coronavirus. Dalam https://www.who.int/indonesia/news/novel-coronavirus/qa-for-public_diakses pada 29 Juni 2020 